\title{
Forgiveness Viewed from Positive Psychology and Islam
}

\author{
Idi Warsah \\ Institut Agama Islam Negeri Curup, Indonesia \\ Qidiwarsah@iaincurup.ac.id
}

Article Information:

Received April 28, 2020

Revised May 7, 2020

Accepted June 4, 2020

Keywords: forgiveness, islam, positive psychology

\begin{abstract}
Conflicts are unavoidable in human life. Thus, for human beings, the attitude of forgiveness is of importance to be well-embedded and sustainably constructed. Resting upon the aforesaid premises, the present study conducted a library research to reveal how forgiveness is viewed from the perspectives of positive psychology and Islam. 102 scientific works reviewed, 58 works were finally selected to be scrutinized in depth. This study revealed that the discourses in the field of positive psychology imply that forgiveness attitude is of importance to be embedded in human beings and continuously constructed by virtue of its positive natural impacts on mental health, good relationships, physical health, and positive well-being. Furthermore, as informed by Islamic teachings, the attitude of forgiveness is also suggested to be well and continuously embedded. As the best Islamic role model for the end-time people, the Prophet Muhammad PBUH already exemplified that humans are indeed to always be forgiving and even to pray for others for the sake of good things that Allah SWT will bestow to. It is worth noting that both positive psychology and Islam encourage humans to be forgiving individuals.
\end{abstract}

\section{INTRODUCTION}

The occurrence of conflicts is inevitable in human life. Conflict means the perceived differences in interests, or a belief that the aspirations of two or more individuals or groups cannot be achieved simultaneously (Büscher, 2018; Powell \& Maoz, 2014; Schilling, Saulich, $\&$ Engwicht, 2018). There are at least several factors influencing the emergence of conflicts in human life. They range from the dynamics of interests, communication styles, economics, work, and personal feelings (Davis, 2016; Jiang \& Shen, 2013; Lauterbach, 2010; Machovec, 2017; Merolla, 2017; Stein, 2017). When an individual makes a mistake, and the other individual finds it difficult to forgive that mistake, the conflict which spawns then tends to be bigger and more prolonged.

An important thing behind the existence of a problem is how to deal with it. Humans are never free from making mistakes, but they can make efforts to minimize probable mistakes which can hurt others. For some people, forgiving is not an easy thing to do. When someone's heart is hurt, it is not always easy for him/her to immediately accept what he/she has got and then to forgive one who broke his/her heart. The extent of friendship and communication cannot always make people capable of solving problems appropriately (Worthington, Witvliet, \& Miller, 2007). However, unwillingness to forgive others' mistakes certainly will not solve the existing problems. That will even only magnify the problems, and those problems will potentially have impacts on physical and psychological health (Biagini, 2019; Ross, Boon, \& Stackhouse, 2017). 
Forgiveness is a variable studied in the field of positive psychology. Positive psychology is a branch of psychological field which focuses on the issue as regards how humans should best live (Kim, Keck, Miller, \& Gonzalez, 2012). Positive psychology offers the importance of forgiveness to assist people in overcoming conflicts. Forgiveness is the ability to let go of the mind and heart of all past pains and bad feelings (Hayward \& Krause, 2013). Forgiveness is associated with a person's ability to defeat anger and eliminate the thoughts of taking revenge on what someone else has done to that person (Amanze \& Carson, 2020; McCullough et al., 1998; Miceli \& Castelfranchijtsb, 2011). If someone's anger is so overflowing and out of control, it will certainly arouse conflicts and disagreement. Anger should be controlled because it can trigger someone to do negative things. Anger tends to manipulate someone whose heart is breaking to reciprocate the pains experienced so that those who have hurt his feelings finally feel the same pains (Diamond, 1977).

Kulcsár (2006) explained that forgiving is important because it has a positive role to maintain physical and mental health. Many researchers, to name a few Aalgaard, Bolen, and Nugent (2016); Pelucchi, Paleari, Regalia, and Fincham (2015); and Sheldon, Gilchrist-Petty, and Lessley (2014), revealed that if a person is unable to forgive others, there will be chaos in him that affects his relationship with others. In addition, some researchers have also reached an agreement that forgiveness is good for health (Rasmussen, Stackhouse, Boon, Comstock, \& Ross, 2019; Svalina \& Webb, 2012; Webb, Hirsch, Visser, \& Brewer, 2013). A study conducted by Friedberg, Suchday, and Shelov (2007) revealed that a higher level of one's likelihood to give forgiveness is associated with lower diastolic blood pressure. Such a condition eventually supports a faster recovery of diastolic blood pressure. The foregoing study implied that as a psychological state, forgiveness is contributive to one's health maintenance. The aforesaid study findings successfully demonstrate that there is a positive relationship between forgiveness and physical healing.

The above elaborations highlight that forgiveness needs to be well-embedded in oneself because it can be a sort of peaceful solution to any conflict phenomenon which is naturally inevitable in human life. As highlighted above, in the field of positive psychology, many researchers emphasized that the attitude of forgiving is beneficial to any individual because such an attitude can make relationships better and positively contribute to one's health. It is also interesting that in the context of religiosity, none of the religions in the world permit the existences of prolonged conflicts. Prior studies have also exhibited that the variables of religiosity and forgiveness are interrelated each other (Barcaccia et al., 2018; Hayward \& Krause, 2013; Lee, 2011; Worthington et al., 2010). Religious discourse as regards forgiveness is also of very importance to be learned. Thus, the current study seeks to explore the concept of forgiveness from various theories in the perspectives of positive psychology and Islam in terms of the meanings of forgiveness, its affiliation with personalities, its aspects and factors, its benefits, and the suggestions given by Islamic teachings about being forgiving individuals.

\section{METHODS}

The current study conducted a library research to review the concepts of forgiveness in the perspectives of positive psychology and Islam. The reviews were led by several themes categorized as the inner circle themes on the basis of the main orientation of this study, wherein those themes extended to forgiveness in positive psychology (FPP), forgiveness and personalities (FP), aspects and factors of forgiveness (AFF), forgiveness and relationships (FR), forgiveness and health and well-being (FHW), and forgiveness and religiosity (FR). The so-called outer circle themes, those which were related but not mainly oriented towards the issue of forgiveness, were also used to help enrich this study. Those themes comprised conflict (C) and anger (A). 
Forgiveness in the Perspective of Positive Psychology

Definitions of forgiveness Interpersonal psychological adjustment to violation;

Healing from a wounded memory, but not erasing;

Motivational changes into avoidance of revenge, openness

to the perpetrator, willingness to make peace;

Minimizing the meaning of violation

Forgiveness and personalities Neuroticism and friendliness encourage forgiveness;

Narcissism discourages forgiveness

Aspects of forgiveness

Throwing away the desire to take revenge;

Disposing of the desire to maintain estrangement;

Triggering the desire to make peace

Factors of forgiveness

Empathy and perspective taking;

Reflection and emphasis;

Closeness, commitment, and satisfaction

Forgiveness is beneficial to relationships

Increasing relationship values;

Making relationships closer

Forgiveness is beneficial to

Supporting physical health;

health and well-being

Supporting psychological health;

Leading to be less depressed;

Leading to be less anxious

Table 1. Forgiveness in the Perspective of Positive Psychology

Forgiveness in the Perspective of Islam

Islam suggests forgiving.

Islam positions forgiveness as a medium of relationships among human being.

The Prophet Muhammad PBUH is the model of a forgiving individual for Muslims.

The Prophet Muhammad PBUH guides Muslims to be forgiving.

Table 2. Forgiveness in the Perspective of Islam

There were 102 scientific works affiliated with the aforesaid themes reviewed by the researcher. After grouping those works resting upon the themes assigned to be oriented, 58 works were finally selected to be scrutinized in depth. From all 58 works, 47 works addressed the inner circle theories of forgiveness in the perspective of positive psychology, religiosity, and Islam, and 11 works addressed theories in the outer circle but related to forgiveness. The 58 works selected dominantly revealed scientific data, wherein those studies have mostly been published in Scopus-indexed International journals over the past decade. See complete data display the summaries, identities, and the coded themes of the aforesaid 58 scientific works resting upon the latest year of publication in descending order (See the Appendix).

The processes of data analysis adopted Miles, Huberman, and Saldana's (2014) model whose elements comprised of data collection, data condensation, data display, and data conclusion. As previously explained, the data were collected from 102 scientific works addressing issues related to forgiveness in the perspectives of positive psychology and Islam. Subsequently, the data were condensed based on several themes oriented towards the study purpose so that there were 58 works used to be studied in-depth. The data were further displayed in the form of a table containing the data summary, organized theoretical 
explanations, and the related discussion. In the end, a set of representative conclusion was drawn.

\section{RESULTS AND DISCUSSION}

This section presents the results and discussion of scientific reviews on the concept of forgiveness from various theories in the perspectives of positive psychology and Islam in terms of the meanings of forgiveness, its affiliation with personalities, its aspects and factors, its benefits, and the suggestions given by Islamic teachings about being forgiving individuals. The Table 1 and Table 2 display the data summary, and under the table are the organized theoretical explanations and the related discussion of the data.

In general, forgiveness is often assumed to be adaptive to interpersonal psychological adjustments to violations (Hourigan, 2016). Forgiveness is a variable studied in the field of positive psychology. Positive psychology is a branch of psychological field which focuses on the issue as regards how humans should best live (Kim, Keck, Miller, \& Gonzalez, 2012). Positive psychology offers the importance of forgiveness to assist people in overcoming conflicts. In the field of positive psychology, forgiveness is assessed with the scales of avoidance measurement, interpersonal motivation for revenge, and psychological adjustment (Prieto-Ursúa et al., 2018; Watson, Rapee, \& Todorov, 2016; Webb et al., 2013; Záhorcová, Halama, \& Enright, 2020). The latent growth curve analysis shows that changes in intraindividual forgiveness are positively correlated with changes in adjustment (Orth, Berking, Walker, Meier, \& Znoj, 2008).

The concept of forgiveness has attracted the attention of the researchers who scrutinized the concepts of personality and social psychology over the past decade (Collier, Ryckman, Thornton, \& Gold, 2010; Fu, Watkins, \& Hui, 2004; Ross, Hertenstein, \& Wrobel, 2007). The foregoing stems from the condition that apart from positive interpersonal effects, forgiveness is often assumed to have a positive intrapersonal effect on the psychological adjustment of forgiving individuals. If forgiveness has the effect of psychological adjustment, then it has important implications for counseling and psychotherapy on painful experiences. The following presentations focus on highlighting several points as regards the definitions of forgiveness, forgiveness and personalities, aspects and factors of forgiveness, and some benefits of forgiveness according to the perspective of positive psychology.

\section{Definitions of forgiveness viewed from positive psychology}

Forgiveness is associated with two things, namely apologizing and forgiving. According to Horwitz (2005), a psychoanalytic expert from Greater Kansas City Psychoanalytic Institute, to do the aforementioned two things, there are a couple of elements involved such as the victims, perpetrators, and various levels of trauma, injuries and injustice. In the other viewpoint, according to Soesilo (2006), forgiveness is healing from a wounded memory, but not erasing. Forgiveness is also interpreted as a way to overcome broken relationships on a pro-social basis (McCullough, Bellah, Kilpatrick, \& Johnson, 2001; McCullough, Kurzban, \& Tabak, 2013; McCullough, Pedersen, Tabak, \& Carter, 2014; McCullough \& Hoyt, 2002; Osei-Tutu, Dzokoto, Oti-Boadi, Belgrave, \& Appiah-Danquah, 2019).

Over the past decade, the first group of "forgiveness" research led by McCullough et al. (2001; 2002), a figure who spent his time on "forgiveness" research, proposed the definition that "forgiveness" is as a set of motivational changes in which an individual becomes (a) less motivated to reciprocate against a relationship partner; (b) less motivated to avoid the perpetrator; and (c) increasingly motivated by good intentions as well as desired to make peace with violators even though the violations are dangerous. McCullough and his peers further refined the aforesaid definition by adding an additional function namely "forgiveness 
system" which produces a motivational change because of an individual's success in promoting the recovery of a beneficial relationship to reduce the impact of interpersonal loss.

The functional definition of "forgiveness" has a conceptual difference from the other theory for example, forgiveness is forgetting a violation, denying the reality of the violation, or trying to minimize the meaning of the violation (Hourigan, 2016), and it allows a closer conceptual relationship between forgiveness and reconciliation (Balkin, Harris, Freeman, \& Huntington, 2014; Bash, 2014). Many theories have carefully distinguished forgiveness from reconciliation, and the latest concept indicates that there is a restoration of relations between perpetrators and victims. In the proposed functional definition of forgiveness, it is plausible to forgive a detrimental offender with making peace. The reason that modern humans are able to forgive others is because human ancestors were tasked with expanding the strategies and benefits of restoring relationships (McCullough et al., 2013).

Forgiveness, like revenge, each has an effect. Forgiveness prepares the victim to reenter a constructive relationship with an adverse offender based on the prospect of capturing the benefits of that relationship, but the motivational changes created by the earlier forgiveness system demand retaliation and deterrent effects. In short, forgiveness can deter the function of revenge system. Forgiveness for McCullough et al. (1998) is a complex phenomenon related to emotions, thoughts and behavior, so that the negative impact and judgment on people who hurt can be reduced. Worthington, Hook, Utsey, Williams, and Neil (2007) talked about the decision to forgive in the aspect of emotion. When someone who is hurt decides to forgive the other, he decides not to take revenge or avoid it. He acts as if the past mistakes did not occur, and if possible and safe, he will seek to make reconciliation.

\section{Forgiveness and personalities}

To some extent, forgiveness and personality are interrelated (Aalgaard et al., 2016; Ross et al., 2007). Personality traits, for example neuroticism and friendliness, can be conceptualized as the filters that shape a person's perceptions of violators, perceptions of the worthiness of violators' rights, values, and safety. McCullough et al. (1998) explain that the inverse relationship of neuroticism and forgiveness is that violations of neuroticism make feelings worse. When people feel as if they have experienced a lot of pains, then forgiveness is seen as compromising their security. Furthermore, because making violations appears more painful, it can also limit the perception that relationships with violators will have values in the future, which will make prospects for relationships less motivating with violators. Thus, such a relationship problem to some extent can be decreased by neuroticism and friendliness personality traits since these traits lead someone to be inclined to be for forgiving.

Narcissism is another personality variable that is negatively related to forgiveness (Fatfouta, Gerlach, Schröder-Abé, \& Merkl, 2015). Narcissistic reluctance to forgive may be made worse by the fact that narcissistic people often undermine the value or appropriateness of caring for others, and are more easily offensive. Hence, it is implied that in order to be more forgiving, an individual need to avoid being narcissistic.

\section{Aspects and factors of forgiveness}

According to McCullough et al. (1998; 2001; 2002; 2010; 2013, 2014), there are several aspects of forgiveness. From the point of view of an individual who gives forgiveness, the aspects are as follows: First, forgiveness can throw away the desire to take revenge against those who have hurt him. Second, forgiveness can dispose of the desire to maintain estrangement (distance) with people who have hurt him. Third, forgiveness can trigger the desire to make peace or to see the well-being of the people who have offended him. In addition, McCullough et al. $(1998 ; 2001 ; 2002 ; 2010 ; 2013,2014)$ also added several factors 
that affect a person's ability to forgive, namely: empathy and perspective taking, reflection and emphasis, and closeness, commitment, and satisfaction.

Empathy and perspective taking make it easier for someone to behave in a pro-social way such as a willingness to help and to forgive others. Affective empathy for people who hurt seems to be a determinant of socio-cognitive behavior to forgive. When those who hurt apologize for their mistakes, people who are hurt tend to feel empathetic so that they end up forgiving even though it is not stated verbally. The ability to use the perspective of another person (perspective taking) also plays a role in building up empathy, where the victim is driven to use the perspective of the person who has hurt by reminding the victim of his mistakes. As regards the factor of reflection and emphasis, most people reflect on the pains they experience, so they find it difficult to forgive others' mistakes. The contemplation of pains will disturb the mind and try to suppress the contemplation to a higher level of avoidance and revenge motivation. Individuals who do not contemplate and suppress on others' mistakes will likely be more forgiving. Furthermore, closeness, commitment, and satisfaction are other important factors that influence forgiveness. It is almost certain that individuals will easily forgive others' mistakes if the mistakes makers had adequate closeness to them. Individuals who are hurt will be easier to forgive those who have high commitment because they feel more disadvantaged if their relationships are ended. Subsequently, individuals who are hurt will find it easier to forgive those who ever fulfilled their needs in the past.

\section{Forgiveness is beneficial to relationships}

The systems of forgiveness evolve in response to the selection of pressures to restore relations, and on average improve the reproductive quality of life which is known as "relationship values". The role of values in determining social relations tends to forgive or reconcile after conflicts occur (Ysseldyk, Matheson, \& Anisman, 2009). It has been proven in the simulation of the evolution of cooperation between individuals and networks. The foregoing has also been discussed by Soesilo (2006) in his article with respect to the case of pressure selection.

The benefits to improve reproductive relations of individuals with different genders such as familial relationships are clearly needed, namely the inclusive benefits. In such a way, to get inclusive benefits, the act of forgiving is expected to be more likely done in the context of family relationships. It is because to forgive the mistakes made by those of familial members or those having close relationships is relatively easier compared to forgiving the people having no proximate relationships (Carr \& Wang, 2012; Rose et al., 2018). In terms of non-relative social relationships, an individual will also be confronted with the selection of pressure to forgive. An individual who can forgive his peer who has made mistakes can get two benefits. First, his forgiveness can be such a constructive feedback to his peer so that his peer changes his behavior in a better way. Second, his forgiveness will open a change for his peer to keep striving to spread good benefits for the present relationship.

\section{Forgiveness is beneficial to health and well-being}

Forgiveness tends to be positively related to the aspects of psychological well-being, physical health, and achieving success (Worthington \& Sandage, 2016). People with a strong tendency to forgive (or a weak tendency to take revenge when hurt by others) have a reduced risk for nicotine dependency disorders, depression, and some anxiety disorders (Toussaint, Worthington, \& Williams, 2015). Forgiveness has also been positively associated with psychological well-being such as high positive emotions, low negative emotions, and high satisfaction with life and physical health (Worthington, Griffin, \& Provencher, 2018). When 
people forgive others, there is a decrease in cardiovascular reactivity such as blood pressure and heart rate (Friedberg et al., 2007).

Forgiveness also affects social support, strong mentality, and physical health. Someone who is ready to forgive is better at maintaining a positive relationship with a partner. He may get better benefits from social support, relationally experienced closeness, commitment, willingness to accommodate, willingness to sacrifice, and cooperation after violations. Conversely, failure to forgive can result in "psychological tension" associated with ambivalence stemming from failure to expand social behavior in relationship (Toussaint et al., 2015).

Psychological tension can potentially reduce life satisfaction and self-esteem as well as increase negative effects. In addition, activating the concept of forgiveness makes people more focused on others, more likely to engage in the acts of caring, and more likely to contribute to a pro-relationship. On the other hand, forgiveness and well-being associations cannot be solely due to static personality processes because for people who are more forgiving, their welfare will be better (measured in terms of low negativity, high positive impact, high life satisfaction, and low levels of self-reporting physical health symptoms) (Chen, Harris, Worthington, \& VanderWeele, 2019).

As depicted by Worthington et al. (2007), research using advanced brain imaging technologies such as positron emission tomography and functional magnetic resonance imaging has successfully revealed differences in the patterns of images of the brain of those who forgive and those who do not forgive. People who do not forgive are closely related to the attitude of anger, which has an impact on the decline in immune function. Individuals who do not forgive have the same brain activity as the brains of people who are stressed, angry, and aggressive. Likewise, there is an imbalance in hormone activity and the forgiving blood state compared to the vindictive or angry people. The pattern of hormones and the composition of chemicals in the blood of an unforgiving person correspond to the pattern of negative emotional hormones related to stressful states. Unforgiveness tends to lead to a higher level of blood viscosity. This state of hormones and blood that is triggered by an unforgiving attitude has a negative impact on health. A very severe attitude of not forgiving can adversely affect health by allowing the existence of stress in that person. This will intensify the reaction of heart and blood vessels when the sufferer remembers the bad events he experienced. Conversely, forgiveness acts as a buffer that can suppress the reaction of the heart and blood vessels while triggering the emergence of positive emotional responses that replace negative emotions.

\section{Islam suggests forgiving}

An understanding of meaning and the need to give forgiveness is deeply shaped by early beliefs and core values. On a broad scale, individuals who identify themselves as religious or spiritual individuals consistently have more forgiving personalities (Hayward \& Krause, 2013; Lee, 2011; Worthington et al., 2010). Forgiveness is a concept with a deep religious root. This is also the basis of social and psychological phenomena (McCullough et al., 1998: 2013; Worthington et al., 2007). The concept of forgiveness has a dual nature, the general and the transcendent natures. In the general concept as illustrated in the material aspect, forgiveness is only one of the social, psychological phenomena. It can be seen why some people seem relatively forgiving, while others seem vengeful. It can be learned why some people find it easier to forgive, but some others are impossible to forgive. The nature of forgiveness can be learned with standard psychological methods. Forgiveness also has other characteristics. These characteristics are spiritual, transcendent, and eternal. These have been a topic of philosophy and theological inquiry for thousands of years. This case is the matter 
related to the Creator, and it is difficult to explain because the relationship is a transcendent relationship.

In the perspective of Islam with respect to forgiveness, Imam Muslim narrated a Hadith sourced from Abu Hurairah r.a. One time the Messenger of Allah asked the companions: "Do you know who is a bankrupt person?", the companions replied: "For us, a bankrupt person is someone who does not have any more money and goods.", the Prophet Muhammad PBUH said: "Verily one who is bankrupt from my people is the one who comes on the day of judgment carrying prayers, fasting and alms, while before, he has chided "this", accused "that", eaten "this" treasure, drained "that" blood, and struck "this". So, to "this", the reward of the goodness from "that" is given, and to "that" the reward of goodness from "this" is given. If the reward of the persons' goodness is over before all the dependents are paid, then the sins of those who have been blamed are given to him (one who is bankrupt), and then he will be thrown into hell. "(See al-Yadhahu wa al-Tabyiin Juz 1: 34).

From the Hadith above, it is very clear that people who are very good in terms of vertical relationship (the relationship with Allah SWT), but not in the case of horizontal relationship (relationships with fellow human beings), are bankrupt people. The foregoing portrays that even though they are diligent in praying, fasting, going on pilgrimage, and so on, on the contrary, they are also diligent in berating, insulting, beating, accusing, and so forth. Reflected on the foregoing, the essence of forgiveness in the relations of human beings is of paramount importance (Nurseha, 2011).

The word forgiveness is really glorified by Allah SWT because in the Qur'an itself there are approximately 12 verses that discuss apologies. This is indeed worth being made moral for humans as social creatures whose lives cannot be separated from other humans. In terms of forgiveness concept, the Prophet Muhammad PBUH is as an example (Uswatun hasanah) for his people. These two things indicate that Islam teaches Muslims the concept of forgiveness. As an example of the attitude of the Prophet Muhammad PBUH, when he preached in the land of Ta'if, the Ta'if people apparently did not accept the presence of the Prophet Muhammad PBUH. Even more than that, they drove away and pelted the Prophet Muhammad PBUH with stones until the Prophet Muhammad PBUH returned home covered in blood. Seeing such an inhuman condition, the angel offered to reciprocate Ta'if people's behavior, but the Prophet said "it does not matter, I forgive them, may their children and grandchildren become obedient people (Khasan, 2017; Nashori, 2008). follows:

The Qur'an in Surah at Taghabun (14) mentions the basic concept of forgiveness as

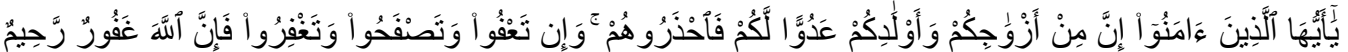

$$
\begin{aligned}
& O \text { believers, Behold, among your wives and your children, there are those who } \\
& \text { become enemies to you. Then, be careful of them, and if you forgive and do not } \\
& \text { rebuke and accept (them), then surely Allah is the most Forgiving and Merciful. }
\end{aligned}
$$

Quraisy Shihab as cited in Nashori (2008) gives the meaning of forgiveness in lughowi as sorry, where the word is adapted from Arabic, al 'afwu. This word in the Qur'an is repeated 34 times. At first this word means "excessive", and then its meaning develops into "elimination". Studies on the correlation of religion and forgiveness are also developing. Some of them are the studies conducted by Barcaccia et al. (2018); Hayward and Krause (2013); Lee (2011); and Worthington et al. (2010). In summary, resting upon their studies, they portrayed that individuals who were high in religious beliefs showed higher reasoning about forgiveness than those who were lower in religious beliefs. 


\section{Lessons taught by positive psychology and Islam about forgiveness}

Grounded in a huge number of theories and scientific findings highlighted above, discourses in the field of positive psychology imply that the attitude of forgiveness is of importance to be well embedded and continuously constructed in ourselves. It is due to positive natural impacts we can get from instilling forgiveness attitude, wherein forgiveness will maintain our positive mental health, maintain advantageous relationships with others, help take care of our physical health, and assist in supporting positive well-being. Furthermore, as informed by Islamic teachings, the attitude of forgiveness is also suggested to be embedded in ourselves. As the best Islamic role model for the end-time people, the Prophet Muhammad PBUH already exemplified that we are indeed to always be forgiving and even to pray for others for the sake of good things that Allah SWT will bestow to. It is clear that both positive psychology and Islam encourage us to be forgiving individuals.

The present study reveals scientific information limited to forgiveness discourse in terms of the definitions, personality affiliation, aspects and factors, and some benefits of forgiveness viewed from positive psychology, and in terms of Islamic encouragement pertinent to being forgiving individuals. The foregoing scientific information will be meaningful and beneficial to the field of counseling, wherein the information reported by the present study can be of positive input that a counselor can embed to clients who are facing conflicts so that they can make use of forgiveness attitude to cope with conflicts and make their lives more peaceful. Further studies are expected to conduct experimentation on counseling treatments making use of forgiveness as a study variable. The experimentation data revealed by such studies will be of reflective empirical information for counselors in the field.

\section{CONCLUSIONS}

Forgiveness is associated with two things namely apologizing and forgiving. To do these two things, there are several elements involved including victims, perpetrators, as well as various levels of trauma, injuries, and injustice. Forgiveness covers three things, namely forgiving others, accepting other people's apologies, and forgiving oneself. Forgiveness is a way to overcome broken relationships on a pro-social basis. This character is related to that relationships built up among individuals or human beings. In forgiving there is a concept that must be considered, namely empathy. Empathy on the concept of forgiveness is illustrated by the balance of individual emotions. This balance will lead to the warmth and positive relations between or among individuals. If an individual has a conflict with another person, and he ignores forgiveness, then it will create tension to bring up the motivations of a new conflict that is exaggerated and hidden where the accumulation is on the attitude of revenge.

Discourses in the field of positive psychology imply that the attitude of forgiveness is of importance to be well embedded and continuously constructed in human beings. It is due to the positive natural impacts which will be got, wherein forgiveness will maintain individuals' positive mental health, maintain advantageous relationships with others, help take care of their physical health, and assist in supporting positive well-being. Furthermore, as informed by Islamic teachings, the attitude of forgiveness is also suggested to be embedded. As the best Islamic role model for the end-time people, the Prophet Muhammad already exemplified that human beings are indeed to always be forgiving and even to pray for others for the sake of good things that Allah SWT will bestow to. It is clear that both positive psychology and Islam encourage people to be forgiving individuals. 


\section{ACKNOWLEDGMENTS}

The author would like to express his gratitude to all colleagues, IAIN Curup, and IAIMNU that have supported the accomplishment of this article in both direct and indirect ways.

\section{AUTHOR CONTRIBUTION STATEMENTS}

The author has contributed to all elements of this article starting out from collecting references, reviewing references, mapping the written concept, analyzing the library research data, drafting the manuscript, editing, to proofreading.

\section{REFERENCES}

Aalgaard, R. A., Bolen, R. M., \& Nugent, W. R. (2016). A literature review of forgiveness as a beneficial intervention to increase relationship satisfaction in couples therapy. Journal of Human Behavior in the Social Environment, 26(1), 46-55. https://doi.org/10.1080/10911359.2015.1059166

Amanze, R. U., \& Carson, J. (2020). Measuring forgiveness: psychometric properties of a new culturally sensitive questionnaire: the Bolton Forgiveness Scale ( BFS ). Mental Health, Religion \& Culture, 1-17. https://doi.org/10.1080/13674676.2020.1716211

Balkin, R. S., Harris, N. A., Freeman, S. J., \& Huntington, S. (2014). The forgiveness reconciliation inventory: An instrument to process through issues of forgiveness and conflict. Measurement and Evaluation in Counseling and Development, 47(1), 3-13. https://doi.org/10.1177/0748175613497037

Barcaccia, B., Pistella, J., Baiocco, R., Pallini, S., Saliani, A. M., Mancini, F., \& Salvati, M. (2018). Forgiveness and religious practice: a study on a sample of Italian preadolescents. Journal of Beliefs and Values, 39(2), 223-232. https://doi.org/10.1080/13617672.2017.1381439

Bash, A. (2014). Forgiveness, Reconciliation and Spirituality. Journal for the Study of Spirituality, 4(1), 58-72. https://doi.org/10.1179/2044024314z.00000000021

Biagini, E. (2019). Islamist women's feminist subjectivities in (r)evolution: the Egyptian Muslim Sisterhood in the aftermath of the Arab uprisings. International Feminist Journal of Politics. https://doi.org/10.1080/14616742.2019.1680304

Büscher, K. (2018). African cities and violent conflict: the urban dimension of conflict and post conflict dynamics in Central and Eastern Africa Africa. Journal of Eastern African Studies, 1-18. https://doi.org/10.1080/17531055.2018.1458399

Carr, K., \& Wang, T. R. (2012). "Forgiveness Isn't a Simple Process: It's a Vast Undertaking": Negotiating and Communicating Forgiveness in Nonvoluntary Family Relationships. Journal of Family Communication, 12(1), 40-56. https://doi.org/10.1080/15267431.2011.629970

Chen, Y., Harris, S. K., Worthington, E. L., \& VanderWeele, T. J. (2019). Religiously or spiritually-motivated forgiveness and subsequent health and well-being among young adults: An outcome-wide analysis. Journal of Positive Psychology, 14(5), 649-658. https://doi.org/10.1080/17439760.2018.1519591

Collier, S. A., Ryckman, R. M., Thornton, B., \& Gold, J. A. (2010). Competitive Personality Attitudes and Forgiveness of Others. The Journal of Psychology: Interdisciplinary and Applied, 144(6), 535-543. https://doi.org/10.1080/00223980.2010.511305

Davis, C. M. (2016). The Ukraine conflict, economic-military power balances and economic sanctions. Post-Communist Economies, 1-32. https://doi.org/10.1080/14631377.2016.1139301 
Diamond, S. R. (1977). The effect of fear on the aggressive responses of anger aroused and revenge motivated subjects. Journal of Psychology: Interdisciplinary and Applied, 95(2), 185-188. https://doi.org/10.1080/00223980.1977.9915877

Fatfouta, R., Gerlach, T. M., Schröder-Abé, M., \& Merkl, A. (2015). Narcissism and lack of interpersonal forgiveness: The mediating role of state anger, state rumination, and state empathy. Personality and Individual Differences, 75, 36-40. https://doi.org/10.1016/j.paid.2014.10.051

Friedberg, J. P., Suchday, S., \& Shelov, D. V. (2007). The impact of forgiveness on cardiovascular reactivity and recovery. International Journal of Psychophysiology, 65(2), 87-94. https://doi.org/10.1016/j.ijpsycho.2007.03.006

Fu, H., Watkins, D., \& Hui, E. K. P. (2004). Personality correlates of the disposition towards interpersonal forgiveness: A Chinese perspective. International Journal of Psychology, 39(4), 305-316. https://doi.org/10.1080/00207590344000402

Hayward, R. D., \& Krause, N. (2013). Trajectories of change in dimensions of forgiveness among older adults and their association with religious commitment. Mental Health, Religion and Culture, 16(6), 643-659. https://doi.org/10.1080/13674676.2012.712955

Horwitz, L. (2005). The capacity to forgive: Intrapsychic and developmental perspectives. Journal of the American Psychoanalytic Association, 53(2), 485-511. https://doi.org/10.1177/00030651050530021401

Hourigan, K. L. (2016). Homicide survivors' definitions of forgiveness: Intrapersonal, interpersonal, and extrapersonal orientations. Violence and Victims, 31(5), 869-887. https://doi.org/10.1891/0886-6708.VV-D-15-00015

Jiang, H., \& Shen, H. (2013). Toward a Theory of Public Relations Practitioners' Own Conflict: Work Versus Life. Journal of Public Relations Research, 25(3), 259-279. https://doi.org/10.1080/1062726X.2013.788446

Khasan, M. (2017). Perspektif Islam dan psikologi tentang pemaafan. Jurnal At-Taqaddum, 9(1), 1-26. Retrieved from Google Scholar

Kim, J. H., Keck, P., Miller, D., \& Gonzalez, R. (2012). Introduction to Positive Psychology: Overview and Controversies. Journal of Asia Pacific Counseling, 2(1), 1-16. https://doi.org/10.18401/2012.2.1.3

Kulcsár, A. (2006). Forgiveness and mental health. Studia Universitatis Babes-BolyaiTheologia Catholica Latina, 1, 93-102. Retrieved from Google Scholar

Lauterbach, W. (2010). The Measurement of Personal Conflict. Psychotherapy Research, 6(3), 213-225. https://doi.org/10.1080/10503309612331331718

Lee, K. H. (2011). The role of spiritual experience, forgiveness, and religious support on the general well-being of older adults. Journal of Religion, Spirituality and Aging, 23(3), 206-223. https://doi.org/10.1080/15528030.2011.533398

Machovec, G. (2017). Conflict of Interest Policies in Library Consortia. Journal of Library Administration, 57(3), 359-366. https:/doi.org/10.1080/01930826.2017.1288967

McCullough, M. E., Bellah, C. G., Kilpatrick, S. D., \& Johnson, J. L. (2001). Vengefulness: Relationships with forgiveness, rumination, well-being, and the big five. Personality and Social Psychology Bulletin, 27(5), 601-610. https://doi.org/10.1177/0146167201275008

McCullough, M. E., \& Hoyt, W. T. (2002). Transgression-related motivational dispositions: Personality substrates of forgiveness and their links to the Big Five. Personality and Social Psychology Bulletin, 28(11), 1556-1573. https://doi.org/10.1177/014616702237583

McCullough, M. E., Kurzban, R., \& Tabak, B. A. (2010). Evolved mechanisms for revenge and forgiveness. Human Aggression and Violence: Causes, Manifestations, and Consequences., 221-239. https://doi.org/10.1037/12346-012 
McCullough, M. E., Kurzban, R., \& Tabak, B. A. (2013). Cognitive systems for revenge and forgiveness. Behavioral and Brain Sciences, 36(1), 1-15. https://doi.org/10.1017/S0140525X11002160

McCullough, M. E., Pedersen, E. J., Tabak, B. A., \& Carter, E. C. (2014). Conciliatory gestures promote forgiveness and reduce anger in humans. Proceedings of the National Academy of Sciences of the United States of America, 111(30), 11211-11216. https://doi.org/10.1073/pnas.1405072111

McCullough, M. E., Rachal, K. C., Sandage, S. J., Worthington, E. L. . J., Brown, S. W., \& Hight, T. L. (1998). Interpersonal forgiving in close relationships: II. Theoretical elaboration and measurement. Journal of Personality and Social Psychology, 75(6), 1586-1603. https://doi.org/10.1037//0022-3514.75.6.1586

Merolla, A. J. (2017). Further Testing Hope's Role in Constructive Conflict Communication. Communication Quarterly, 1-21. https://doi.org/10.1080/01463373.2017.1291529

Miceli, M., \& Castelfranchijtsb, C. (2011). Forgiveness : A Cognitive Motivational Anatomy. Journal for the Theory of Social Behaviour, 41(3). Retrieved from Google Scholar

Miles, M. B., Huberman, A. M., \& Saldana, J. (2014). Qualitative data analysis: A methods sourcebook. Thousand Oaks, California 91320: SAGE Publications, Inc. Retrieved from Google Scholar

Nashori, H. F. (2008). Psikologi Sosial Islami. Bandung: Refika Aditama. Retrieved from Google Scholar

Nurseha, A. (2011). Pengusung konsep maaf. Retrieved from Google Scholar

Orth, U., Berking, M., Walker, N., Meier, L. L., \& Znoj, H. (2008). Forgiveness and psychological adjustment following interpersonal transgressions: A longitudinal analysis. Journal of Research in Personality, 42(2), 365-385. https://doi.org/10.1016/j.jrp.2007.07.003

Osei-Tutu, A., Dzokoto, V. A., Oti-Boadi, M., Belgrave, F. Z., \& Appiah-Danquah, R. (2019). Explorations of Forgiveness in Ghanaian Marriages. Psychological Studies, 64(1), 70-82. https://doi.org/10.1007/s12646-018-0471-9

Pelucchi, S., Paleari, F. G., Regalia, C., \& Fincham, F. D. (2015). Self-forgiveness in romantic relationships: 2. Impact on interpersonal forgiveness. Family Science, 6(1), 181-190. https://doi.org/10.1080/19424620.2015.1082048

Powell, B. M., \& Maoz, I. (2014). Barriers to conflict resolution in landscapes of asymmetric conflict: Current issues and future directions. Dynamics of Asymmetric Conflict, 7(2), 226-235. Retrieved from Google Scholar

Prieto-Ursúa, M., Jódar, R., Gismero-Gonzalez, E., Carrasco, M. J., Martínez, M. P., \& Cagigal, V. (2018). Conditional or Unconditional Forgiveness? An Instrument to Measure the Conditionality of Forgiveness. International Journal for the Psychology of Religion, 28(3), 206-222. https://doi.org/10.1080/10508619.2018.1485829

Rasmussen, K. R., Stackhouse, M., Boon, S. D., Comstock, K., \& Ross, R. (2019). Metaanalytic connections between forgiveness and health: the moderating effects of forgiveness-related distinctions. Psychology and Health, 34(5), 515-534. https://doi.org/10.1080/08870446.2018.1545906

Rose, A., Anderson, S., Miller, R., Marks, L., Hatch, T., \& Card, N. (2018). Longitudinal Test of Forgiveness and Perceived Forgiveness as Mediators between Religiosity and Marital Satisfaction in Long-Term Marital Relationships. American Journal of Family Therapy, 46(4), 356-374. https://doi.org/10.1080/01926187.2018.1547667

Ross, R. W. J., Boon, S. D., \& Stackhouse, M. R. D. (2017). Redefining unforgiveness: Exploring victims' experiences in the wake of unforgiven interpersonal transgressions. Deviant Behavior, 1-13. https://doi.org/10.1080/01639625.2017.1399747 
Ross, S. R., Hertenstein, M. J., \& Wrobel, T. A. (2007). Maladaptive correlates of the failure to forgive self and others: Further evidence for a two-component model of forgiveness. Journal of Personality Assessment, 88(2), 158-167. https://doi.org/10.1080/00223890701267985

Schilling, J., Saulich, C., \& Engwicht, N. (2018). A local to global perspective on resource governance and conflict. Conflict, Security \& Development, 18(6), 433-461. https://doi.org/10.1080/14678802.2018.1532641

Sheldon, P., Gilchrist-Petty, E., \& Lessley, J. A. (2014). You Did What? The Relationship Between Forgiveness Tendency, Communication of Forgiveness, and Relationship Satisfaction in Married and Dating Couples. Communication Reports, 27(2), 78-90. https://doi.org/10.1080/08934215.2014.902486

Soesilo, V. A. (2006). Mencoba Mengerti Kesulitan untuk Mengampuni : Perjalanan Menuju Penyembuhan Luka Batin yang Sangat Dalam. Veritas : Jurnal Teologi Dan Pelayanan, 7(1), 115-125. https://doi.org/10.36421/veritas.v7i1.158

Stein, A. A. (2017). Ethnicity, extraterritoriality, and international conflict. Ethnic and Racial Studies, 40(12), 1-19. https://doi.org/10.1080/01419870.2017.1277032

Svalina, S. S., \& Webb, J. R. (2012). Forgiveness and health among people in outpatient physical therapy. Disability and Rehabilitation, 34(5), 383-392. https://doi.org/10.3109/09638288.2011.607216

Toussaint, L. L., Worthington, E. L., J., \& Williams, D. R. (2015). Forgiveness and health: Scientific evidence and theories relating forgiveness to better health. New York: Springer. Retrieved from Google Scholar

Watson, H., Rapee, R., \& Todorov, N. (2016). Imagery rescripting of revenge, avoidance, and forgiveness for past bullying experiences in young adults. Cognitive Behaviour Therapy, 45(1), 73-89. https://doi.org/10.1080/16506073.2015.1108360

Webb, J. R., Hirsch, J. K., Visser, P. L., \& Brewer, K. G. (2013). Forgiveness and health: Assessing the mediating effect of health behavior, social support, and interpersonal functioning. Journal of Psychology: Interdisciplinary and Applied, 147(5), 391-414. https://doi.org/10.1080/00223980.2012.700964

Worthington, E. L., J., Griffin, B. J., \& Provencher, C. (2018). Forgiveness. In J. E. Maddux (Ed.), Social psychological foundations of well-being and life satisfaction (pp. 148167). New York: Routledge. Retrieved from Google Scholar

Worthington, E. L., J., \& Sandage, S. J. (2016). Forgiveness and spirituality in psychotherapy: A relational approach. Washington, DC: American Psychological Association. Retrieved from Google Scholar

Worthington, E. J., Hook, J., Utsey, S., Williams, J., \& Neil, R. (2007). Decisional and emotional forgiveness. In International Positive Psychology Summit. Washington, DC. Retrieved from Google Scholar

Worthington, E. L., Greer, C. L., Hook, J. N., Davis, D. E., Gartner, A. L., Jennings, D. J., ... Toussaint, L. (2010). Forgiveness and spirituality in organizational life: Theory, status of research, and new ideas for discovery. Journal of Management, Spirituality and Religion, 7(2), 119-134. https://doi.org/10.1080/14766081003765273

Worthington, E. L., Witvliet, C. V. O., \& Miller, P. P. (2007). Forgiveness, Health, and WellBeing: A Review of Evidence for Emotional Versus Decisional Forgiveness, Dispositional Forgivingness, and Reduced Unforgiveness. Journal of Behavioral Medicine, 30, 291-302. https://doi.org/10.1007/s10865-007-9105-8

Ysseldyk, R., Matheson, K., \& Anisman, H. (2009). Forgiveness and the appraisal-coping process in response to relationship conflicts: Implications for depressive symptoms. Stress, 12(2), 152-166. https://doi.org/10.1080/10253890802228178 
Záhorcová, L., Halama, P., \& Enright, R. D. (2020). Forgiveness as a Factor of Adjustment in Bereaved Parents. Journal of Loss and Trauma, 25(2), 188-203. https://doi.org/10.1080/15325024.2019.1664786

Copyright holder :

(c) Warsah, I. (2020)

First publication right :

(c) Islamic Guidance and Counseling Journal

This article is licensed under:

CC-BY-SA 